УДК 631.559:631.8:633.15(292.485)

(C) 2016

Срмакова Л. М., кандидат сільськогосподарських наук, Свистунов Ю. В., здобувач

(науковий керівник - кандидат сільськогосподарських наук Л. М. Срмакова)

Національний університет біоресурсів і природокористування України

\title{
ФОРМУВАННЯ ВРОЖАЮ ТА ЯКОСТІ ЗЕРНА КУКУРУДЗИ ЗАЛЕЖНО ВІД УДОБРЕННЯ В ЛІВОБЕРЕЖНОМУ ЛІСОСТЕПУ
}

\section{Рецензент - кандидат сільськогосподарських наук В. М. Рожко}

Наведено результати наукових досліджень щзодо впливу позакореневого підживлення посівів добривом «Вітазим» на продуктивність гібридів кукурудзи на чорноземах типових. Дослідження проводилися впродовж 2015-2016 років в умовах ТОВ «ПКЗ-АГРО» Пирятинського району Полтавської області. На основі опрацювання результатів наукових досліджень встановлено, шчо для реалізації потенціалу продуктивності кукурудзи та отримання урожайності на рівні 10,0 m/га доцільно застосовувати добриво «Вітазим» із нормою витрати 1 л/га у фазу 7-9 листків на фоні розрахункової норми мінеральних добрив та впроваджувати у виробництво високопродуктивні гібриди кукурудзи Окксіжен та Алекксандра.

Ключові слова: кукурудза, гібрид, добриво «Вітазим», фон живлення, продуктивність, якість зерна, мікродобриво.

Постановка проблеми. Останнім часом Україна займає провідні позиції на світовому ринку як експортер зернових культур. Це пов'язано зі зростанням обсягів виробництва зернових культур, які у 2013 році досягли рівня 63 млн тонн. Проте варто зазначити, що передумовою такого зростання слід завдячити підвищенню конкурентоспроможності вітчизняної кукурудзи, частка якої у валовому зборі зернових культур досягла $49 \%$, а валове виробництво зерна сягнуло рівня 31 млн тонн [1].

Таким здобуткам ми завдячуємо плідній праці селекціонерів, які забезпечили виробництво новими високопродуктивними ранньостиглими та середньоранніми гібридами кукурудзи, адаптованими до умов вирощування. Проте значний відсоток у підвищенні продуктивності кукурудзи належить інтенсифікації технологій вирощування та застосуванню позакореневих підживлень посівів сучасними добривами нового покоління, насиченими макро- та мікроелементами відповідно до потреби культури.

Кукурудза внаслідок своїх біологічних особливостей має специфічні вимоги до забезпечення елементами живлення. У перші два місяці куку- рудза росте досить повільно, тому поживні речовини в цей період використовуються нею в повній мірі, а відтак слід вносити добрива у легкорозчинній формі. Максимальну кількість поживних речовин (70-80 \%) рослини кукурудзи поглинають у період від викидання волоті і рилець до трьох-чотирьох тижнів після цвітіння. Зважаючи на це, забезпечення поживними речовинами повинне узгоджуватися 3 потребами в них рослин кукурудзи у конкретній фазі [2].

Кукурудза (за результатами наукових досліджень Д. Шпаара) має високу потребу в забезпеченні мікроелементами цинком і марганцем та середню - міддю і бором. Встановлено, що кукурудза в процесі вегетації поглинає значну кількість мікроелементів: до 80 г/га марганцю, 350400 г/га цинку, близько 70 г/га бору та 50-60 г/га міді. Отже, за певних умов може виникнути необхідність підживлення посівів кукурудзи сучасними добривами, що містять ці елементи.

На ранніх фазах росту і розвитку рослини кукурудзи через слаборозвинену кореневу систему страждають як від нестачі фосфору, так і марганцю і цинку. У фазі інтенсивного росту рослин кукурудзи потреба в цих елементах висока, оскільки вони активізують ферментативну діяльність. Бор особливо позитивно діє на запліднення, тому що сприяє росту пилкової трубки. У стадії розвитку по коду ВВСН від 13 до 17 можна використовувати багатокомпонентні мікродобрива листкової дії різного складу, які добре поєднуються з гербіцидами [2].

Аналіз останніх досліджень і публікацій, у яких започатковано розв'язання проблеми. Кукурудза є культурою зі значно більшими потребами в удобренні, порівняно з іншими зерновими культурами. Залежно від рівня урожайності засвоюється різна кількість поживних речовин, зокрема і велика кількість макро- та мікроелементів. Основними 3 них $є$ калій, мідь, залізо та цинк. Багатокомпонентним комбінованим органомінеральним, мікробіологічно-синтезованим добривом, яке зможе забезпечити рослини кукуру- 
дзи цими елементами є добриво «Вітазим».

«Вітазим» завдяки своїм властивостям та компонентному складу може підвищити продуктивність кукурудзи шляхом збільшення інтенсивності фотосинтезу рослин, кращої фіксації сонячної енергії у формі вуглецевих сполук, збільшенні площі листкової поверхні культури на 30$50 \%$ та розмірів і маси кореневої системи рослин, іiі вегетативної та генеративної маси, підвищення стійкості рослин кукурудзи до стресових факторів.

У свій час вивченням особливостей та ефективності дії рідкого добрива та стимулятора росту рослин «Вітазим» на сільськогосподарські культури в умовах центрального Лісостепу України займались у Вінницькій ДСГДС Інституту кормів УААН та в низці провідних сільськогосподарських компаній на базі їх науково-дослідних відділів. Результати досліджень засвідчують, що дане добриво потребує більш ретельного вивчення по кожній сільськогосподарській культуpi, зокрема і кукурудзі.

Мета дослідження - виявити особливості росту та розвитку рослин, формування врожайності та якості зерна гібридів кукурудзи залежно від фону мінерального живлення та позакореневого підживлення посівів органо-мінеральним, мікробіологічно-синтезованим добривом із сильнодіючим біостимулюючим ефектом «Вітазим».

Матеріали і методика досліджень. Дослідження проводилися впродовж 2015-2016 років в умовах ТОВ «ПКЗ-АГРО» Пирятинського району Полтавської області на чорноземах типових. Двофакторний дослід проводили у чотириразовій повторності за загальноприйнятими методиками для даної природно-кліматичної зони.

Для досягнення поставленої мети було закладено польовий дослід.

Фактор А. Гібрид:

1. Дніпровський 310 МВ-контроль;

2. Окксіжен;

3. Алекксандра.

Фактор В. Фон мінерального живлення:

1. Фон 1 (розрахунковий) - $100 \%$,

2. Фон $2-50 \%$;

Фактор С. Позакореневе підживлення:

1. Без підживлення (К) - вода;

2. «Вітазим» 0,5 л/га у фазу 5-6 листків;

3. «Вітазим» 1,0 л/га у фазу 5-6 листків;

4. «Вітазим» 1,5 л/га у фазу 5-6 листків;

5. «Вітазим» 0,5 л/га у фазу 7-9 листків;

6. «Вітазим» 1,0 л/га у фазу 7-9 листків;

7. «Вітазим» 1,5 л/га у фазу 7-9 листків.

Результати досліджень. Основним критерієм ефективності технології вирощування будь-якої культури є рівень їі урожайності. Встановлено, що обробка посівів досліджуваних гібридів кукурудзи у фазу семи-дев'яти листків добривом «Вітазим» у нормі 1 л/га забезпечила формування вищої урожайності на фоні повного мінерального добрива. Урожайність за внесення 50 \% розрахункової норми мінеральних добрив та застосування «Вітазиму»у зазначену фазу на 0,2 т/га поступилася кращому варіанту, що свідчить про можливість економії частини мінеральних добрив та зменшення витрат на вирощування, що досить важливо для господарств середнього рівня ресурсного забезпечення. Врожайність зерна суттєво змінювалась і залежно від гібриду. Так, найвищу врожайність за застосування добрива «Вітазим» формували гібриди Алекксандра та Окксіжен, яка становила відповідно 10,8 та 10,3 т/га. Гібрид Дніпровський $310 \mathrm{MB}$ мав дещо нижчу врожайність, яка становила 9,6 т/га. Кращим варіантом по врожайності виявився шостий за застосування «Вітазиму» в нормі 1 л/га у фазу 7-9 листків на фоні повного мінерального добрива.

Добриво «Вітазим» позитивно впливало на основні показники якості зерна кукурудзи. Вміст білка в зерні досліджуваних гібридів кукурудзи залежав від норми мінерального живлення, біологічних особливостей гібриду та погодних умов вегетаційного періоду культури. За вирощування без добрив у зерні кукурудзи вміст його становив 7,73-8,49 \%. У середньому по гібридах за період 2015-2016 рр. вміст білка був у межах 8,02-7,8 \%. Внесення мінеральних добрив (фон) сприяло збільшенню вмісту білка на 0,85-1,07 \% порівняно з контролем. Обробка посівів добривом «Вітазим» забезпечила зростання вмісту білка до 8,59-8,81 \%. Таку різницю між гібридами обумовлено i їх біологічними особливостями. Найбільший вміст білка відмічено у гібрида Алекксандра $(9,18 \%)$.

Обробка посівів препаратом «Вітазим» порізному вплинула і на інші показники якості зерна гібридів кукурудзи, зокрема такі як крохмаль та жир. Встановлено, що чіткої закономірності впливу добрива «Вітазим» на вміст крохмалю не виявлено як і по фону мінерального живлення. Більший вміст відмічено у гібрида Окксіжен на контролі. В цілому вміст крохмалю залежно від застосування «Вітазиму» змінювався несуттєво.

Що стосується такого показника як вміст жиру в зерні кукурудзи, то найбільший вміст його був на контрольному варіанті і становив 3,99 \%. Внесення добрив (фон) призвело до незначного зниження вмісту жиру в зерні в середньому по гібридах від 3,70 до 3,61 \%. Найменший вміст жиру був зафіксований у гібрида Дніпровський 310 MB. 
Висновок. Результати проведених досліджень показали, що для отримання врожайності зерна кукурудзи в межах 10,3-10,8 т/га доцільно застосовувати добриво «Вітазим» у нормі 1 л/га у

\section{БІБЛІОГРАФІЯ}

1. Сільське господарство України за 2013 рік. Статистичний щорічник. - К. : Державна служба статистики України, 2013. - 383 с.

2. Кукурудза. Вирощування, збирання, консер- фазу 7-9 листків на фоні повного мінерального добрива за впровадження у виробництво найбільш продуктивних, адаптованих до умов вирощування гібридів Алекксандра та Окксіжен.

вування і використання / [Шпаар Д. та ін.] ; під загальною редакцією Д. Шпаара. - К. : Альфастевія ЛТД, 2009. - 396 с. 